\title{
Ocena jakości złączy spawanych w konstrukcjach stalowych kontrolowanych radiograficznie, na podstawie poziomu jakości B+ wg PN-EN 1090-2
}

\section{Quality assessment of welded joints in steel structures subjected to radiographic examination, basing on the quality level B+ acc. to PN-EN 1090-2}

\section{Streszczenie}

Wymagany poziom jakości złączy spawanych powinien być ustalony przed ich wykonaniem, najlepiej na etapie projektowania. W niektórych konstrukcjach może zaistnieć konieczność ustalania różnych poziomów jakości w tym samym złączu spawanym lub wprowadzenie szczególnych wymagań dla przyjętego poziomu jakości. Fakt ten ujęto w PN-EN 1090-2. Ten poziom jakości oznaczono symbolem B+, który w większości przypadków dotyczy niezgodności wykrywalnych metodą radiograficzną. Wykonano porównanie zasad oceny jakości złączy spawanych na podstawie radiogramów, według wymagań: PN-EN ISO 5817, PN-EN 12517-1 i PN-EN 1090-2. Porównanie powinno przyczynić się do zoptymalizowania tych zasad ze względu na przedstawione w normach wymagania.

\section{Wstęp}

Identyfikacja niezgodności występujących w złączach spawanych możliwa jest wyłącznie za pomocą badań nieniszczących. Na podstawie uzyskanych wyników badań określa się zwykle długość, szerokość

Mgr inż. Janusz Czuchryj, mgr inż. Sławomir Sikora, mgr inż. Krzysztof Staniszewski - Instytut Spawalnictwa w Gliwicach.

\section{Abstract}

The required quality level of welded structures should be determined prior to their execution, preferably in the designing stage. For some structures the need for determining various quality levels in the same welded joint may occur or special requirements for the established quality level should be introduced. These conditions can be observed in PN-EN 1090-2 standard. Such quality level has been denoted with symbol $\mathrm{B}+$, which in the majority of cases concerns the imperfections detected using radiographic method. For this reason the study has been undertaken aimed at the comparison of the rules of quality assessment of welded joints on the basis of radiographs in accordance with the requirements of the following standards: PN-EN ISO 5817, PN-EN 12517-1 and PN-EN 1090-2. This comparison should contribute to the optimisation of these rules in respect of the requirements determined in the standards.

i wysokość niezgodności oraz określa jakość wykonanych połączeń.

Wymagany poziom jakości złączy spawanych powinien być ustalony przed ich wykonaniem, najlepiej na etapie projektowania. Dla pojedynczego złącza najczęściej ustala się jeden poziom jakości. W niektórych konstrukcjach może zaistnieć konieczność ustalania różnych poziomów jakości w tym samym złączu spawanym lub wprowadzenie szczególnych wymagań dla przyjętego poziomu jakości.

Ostatni przypadek dotyczy konstrukcji odpowiedzialnych, tzn. takich, których awaria (zniszczenie) 


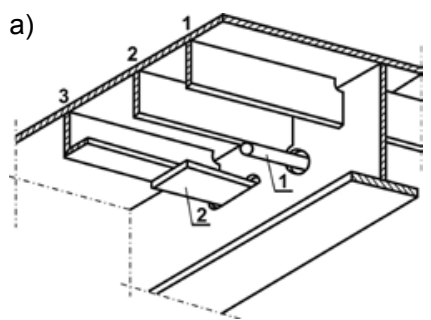

b)

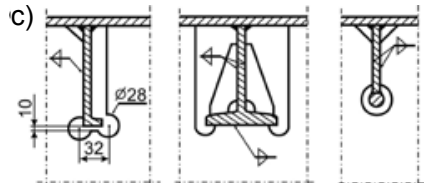

d)

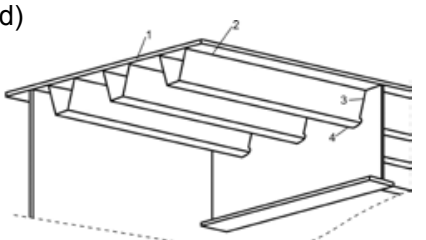

Rys. 1. Przykłady użebrowanych płyt pomostowych: a) ortotropowej; 1 - bezpośrednio przyspawane, 2 i 3 - z nakładkami ciągłości; b) w moście autostradowym - schemat przekroju poprzecznego mostu; c) przechodzące w sposób ciągły przez środniki poprzecznic pomostu; d) szczegóły wykonania użebrowań; 1 - płyta pomostu, 2 - połączenie spawane usztywnienia płyty pomostu żebrem podłużnym, 3 - połączenie spawane żebra podłużnicy i poprzecznicy, 4 - wycięcie w środniku belki poprzecznej

Fig. 1. Examples of ribbed deck plate: a) orthotropic: 1 - welded on directly, 2 and 3 - with continuity strap; b) motorway bridge - a diagram of a bridge cross section; c) crossing continuously through the webs of a deck crossbars; d) details of ribs erection; 1 - deck plate, 2 - welded joint of a deck plate with the longitudinal rib, 3 - welded joint of a stringer and a crossbeam, 4 - cut out in a crossbeam web

zagraża nadzwyczajnymi konsekwencjami. Przykładem takich konstrukcji mogą być płyty w pomostach obiektów przemysłowych, w których wykorzystuje się blachy jako elementy nie tylko pokryciowe, ale również jako elementy nośne, dzięki zastosowaniu odpowiednich użebrowań (rys. 1) [1].

Ustalenie szczególnych wymagań dla przyjętego poziomu jakości ujęto w PN-EN 1090-2, w której dla złączy spawanych konstrukcji stalowych oraz złączy spawanych płyt pomostowych w mostach stalowych, dla poziomu jakości B (zdefiniowanego zgodnie z PN-EN ISO 5817) ustalono wymagania dodatkowe. Ten poziom jakości oznaczono symbolem B+. Większość wymagań dodatkowych dotyczy niezgodności wykrywalnych metodą radiograficzną. Ponieważ radiografia zajmuje ważną pozycję wśród najczęściej stosowanych metod badań nieniszczących, znajomość obowiązujących w tym zakresie zasad należy uznać $z a$ istotną $z$ punktu widzenia diagnostyki technicznej. $Z$ tego powodu podjęto prace, polegajacą na porównaniu zasad oceny jakości złączy spawanych na podstawie radiogramów, wg wymagań norm: PN-EN ISO 5817, PN-EN 12517-1 i PN-EN 1090-2. Porównanie powinno przyczynić się do zoptymalizowania tych zasad ze względu na przedstawione w normach wymagania.

\section{Poziomy jakości, poziomy akceptacji wskazań i klasy wykonania konstrukcji}

W PN-EN ISO 5817, dla materiałów o grubości większej lub równej 0,5 mm, określono trzy zbiory wartości wymiarowych dobieranych do danego zastosowania. Zbiory te nazwano poziomami jakości i oznaczono literami B, C i D. Poziom B odpowiada najwyższym wymaganiom wobec wykonywanych złączy spawanych, natomiast poziom D wymaganiom najniższym. Poziom C stanowi wymagania pośrednie. Zaleca się, aby podczas wyboru poziomu jakości uwzględnić takie czynniki jak: ważność projektu, przewidywane procesy obróbcze, rodzaj działających obciążeń, warunki eksploatacji wyrobu oraz konsekwencje jego ewentualnej awarii. Ważny czynnik wyboru stanowią również zagadnienia ekonomiczne. Norma obejmuje rodzaje niezgodności spawalniczych, które są charakterystyczne dla różnych metod spawania. Rozważa się tylko te niezgodności, które odnoszą się do zastosowanego procesu spawalniczego. Normę PN-EN ISO 5817 wprowadzono jako ogólny przepis odbiorowy, do którego można odnieść wyniki różnych metod badań nieniszczących. W obecnej postaci normy jest to jednak niewykonalne. Nie uwzględniono bowiem podstaw fizycznych, specyfiki i zakresu zastosowania poszczególnych metod badawczych. Dlatego opracowano normy określające tzw. poziomy akceptacji wskazań, które te niezgodności eliminują. Poziomy akceptacji niezgodności spawalniczych wykrywanych radiograficznie określono w PN-EN 12517-1 i oznaczono je 1, 2 i 3. Poziomy akceptacji wskazań skorelowano z poziomami jakości (PN-EN 17635, tabl. I, rys. 2).

Jak wynika z tablicy I i rysunku 2, poziomy akceptacji wskazań 1, 2 i 3 dla badań radiograficznych

Tablica I. Korelacja między poziomami jakości a poziomami akceptacji wskazań dla badań radiograficznych

Table I. Correlation between quality levels and acceptation levels for indications during radiographic examination

\begin{tabular}{|c|c|}
\hline \multicolumn{2}{|c|}{ Korelacja } \\
\hline $\begin{array}{c}\text { Poziomy jakości wg } \\
\text { PN-EN ISO 5817 }\end{array}$ & $\begin{array}{c}\text { Poziomy akceptacji wskazań wg } \\
\text { PN-EN 12517-1 }\end{array}$ \\
\hline B & 1 \\
\hline C & 2 \\
\hline D & 3 \\
\hline
\end{tabular}

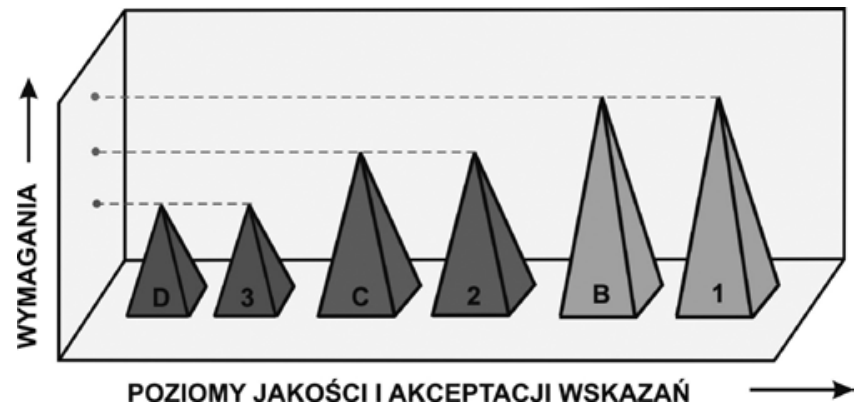

Rys. 2. Poziomy jakości wg PN-EN ISO 5817 i poziomy akceptacji wskazań wg PN-EN 12517-1 w zależności od wymagań

Fig. 2. Quality levels in accordance with PN-EN ISO 5817 and acceptation levels for indications in accordance with PN-EN 12517-1 depending on the assigned requirements 
Tablica II. Zależności zalecane przy ustalaniu klas wykonania konstrukcji oraz obowiązujące dla nich kryteria akceptacji (poziomy jakości) niezgodności spawalniczych

Table II. The relations recommended in the determination of execution classes of the structures and related acceptation criteria (quality levels) of welding imperfections

\begin{tabular}{|c|c|c|c|c|c|c|c|c|c|c|c|c|}
\hline Określenie & & & & & & Zale & żności & & & & & \\
\hline Klasy konsekwencji & & $\mathrm{CC}$ & & & & & $\mathrm{C} 2$ & & & & $\mathrm{CC} 3$ & \\
\hline Kategorie użytkowania & & & & 22 & & $\mathrm{C1}$ & & 22 & $\mathrm{SS}$ & $\mathrm{C} 1$ & & 22 \\
\hline Kategorie produkcji & PC1 & $\mathrm{PC} 2$ & PC1 & PC2 & PC1 & PC2 & PC1 & PC2 & PC1 & PC2 & PC1 & PC2 \\
\hline Klasy wykonania konstrukcji & EXC1 & EXC2 & EXC2 & EXC2 & EXC2 & EXC2 & EXC3 & EXC3 & EXC3*) & EXC3*) & EXC3* & EXC4 \\
\hline $\begin{array}{l}\text { Poziom jakości złącza } \\
\text { wg PN-EN ISO } 5817\end{array}$ & $\mathrm{D}$ & & & $C, D^{* *}$ & & & & & B & & & $B+{ }^{*+*}$ \\
\hline $\begin{array}{l}\text { *) Klasa EXC4 dotyczy konstru } \\
\text { niebezpieczne. Uwaga: w prz } \\
{ }^{* *} \text { Dopuszcza się poziom jako } \\
\text { krateru (2025). } \\
\text { "*) Poziom jakości nieokreślon } \\
\text { ności w postaci niewłaściweg }\end{array}$ & $\begin{array}{l}\text { cjalnyc } \\
\text { gdy kl } \\
\text { a niez } \\
\text { wyma } \\
\text { u spoin }\end{array}$ & $\begin{array}{l}\text { w rozur } \\
\text { sa wyko } \\
\text { odności }\end{array}$ & $\begin{array}{l}\text { nieniu p } \\
\text { nania ni } \\
\text { w posta }\end{array}$ & $\begin{array}{l}\text { zepisów } \\
\text { e jest okr } \\
\text { ci: podto } \\
5817 \text {. U } \\
\text { yklejenia }\end{array}$ & $\begin{array}{l}\text { krajow } \\
\text { eślona } \\
\text { pień }(5 \\
\text { waga: } \\
\text { (4014 }\end{array}$ & $\begin{array}{l}\text { ch lub k } \\
\text { tosuje } \\
11,501 \\
\text { zy usta }\end{array}$ & $\begin{array}{l}\text { nstrukc } \\
\text { e klasę } \\
\text {, nawi } \\
\text { aniu kry }\end{array}$ & $\begin{array}{l}\text { których } \\
\text { XC2. } \\
(506), \text { ś } \\
\text { riów akc }\end{array}$ & $\begin{array}{l}\text { zniszcze } \\
\text { śladu zaj } \\
\text { ceptacji n }\end{array}$ & $\begin{array}{l}\text { arzenie mo } \\
\text { hie uwz }\end{array}$ & $\begin{array}{l}\text { e być s } \\
(601) \text { i } \\
\text { lędnion }\end{array}$ & $\begin{array}{l}\text { zególnie } \\
\text { kończeń } \\
\text { iezgod- }\end{array}$ \\
\hline
\end{tabular}

odpowiadają poziomom jakości B, C i D. Oznacza to, że poziom akceptacji 1 jest równoważny jakości $B$, poziom akceptacji 2 poziomowi jakości C i poziom akceptacji 3 jakości D. Jednak sposób określania wartości granicznych niezgodności spawalniczych w przypadku poziomów akceptacji jest nieco inny niż w przypadku poziomów jakości.

W PN-EN1090-2, dotyczącej wykonywania konstrukcji ze stali w gatunku nie wyższym niż S960, niezależnie od ich rodzaju i kształtów (np. budynki, mosty, elementy pełnościenne kratowe, narażone na zmęczenie lub oddziaływania sejsmiczne itp.), wyspecyfikowano wymagania w odniesieniu do tzw. klas wykonania konstrukcji. Zgodnie $\mathrm{z}$ tą normą zdefiniowano cztery klasy wykonania konstrukcji: EXC1, EXC2, EXC3 i EXC4. Klasa EXC1 charakteryzuje się najniższymi wymaganiami, natomiast klasa EXC4 najwyższymi. Klasy wykonania mogą być stosowane do całej konstrukcji, części konstrukcji lub do jej elementów. W ramach jednej konstrukcji może zatem obowiązywać kilka klas wykonania. Element lub grupa elementów zwykle przypisywane są do jednej klasy wykonania. Klasy wykonania konstrukcji ustala się, uwzględniając czynniki wpływające na niezawodność konstrukcji (klasy konsekwencji, kategorie użytkowania, kategorie produkcji), co determinuje stosowanie określonych wymagań związanych z wykonaniem danej konstrukcji (tabl. II).

Jak wynika z tablicy II, przy wykonywaniu konstrukcji zgodnie z najmniej rygorystyczną klasą wykonania EXC1 wymagany jest poziom jakości $D$ złączy spawanych. Przy wymaganiach klasy wykonania EXC2 obowiązują poziomy jakości C i D (określone ze względu na obecność tylko niektórych niezgodności). Jeżeli w dokumentacji (projekcie) konstrukcji nie podano klasy jej wykonania, to w każdym przypadku należy stosować klasę EXC2. Przy bardzo rygorystycznej klasie wykonania konstrukcji EXC3 wymagany jest poziom jakości B. Podczas wykonywania konstrukcji specjalnych (klasa EXC4) obowiązują najwyższe wymagania dotyczące złączy spawanych, czyli poziom jakości B+.
Poziom jakości B+ wymagany jest również wtedy, kiedy wykonuje się konstrukcje, których awaria lub zniszczenie mogą być niebezpieczne.

Przewiduje się szeroki zakres zastosowania PN--EN1090-2 w praktyce przemysłowej. Zdaniem autorów opracowania, przeanalizowanie zaproponowanych wymagań na tle dotychczas stosowanych przepisów jest niezwykle istotne.

\section{Kryteria akceptacji niezgodności spawalniczych na podstawie badań radiograficznych według PN-EN ISO 5817, PN-EN 12517 i PN-EN 1090-2}

Porównanie kryteriów akceptacji niezgodności spawalniczych, wykrywanych metodą radiograficzną, przeprowadzono dla doczołowych złączy spawanych ze stali. Wymagania obowiązujące dla poszczególnych niezgodności na poziomie jakości B i B+ oraz poziomie akceptacji 1 zestawiono $w$ tablicy III.

Z analizy tablicy III wynika, że zgodnie z oczekiwaniami kryteria akceptacji niezgodności spawalniczych określone na poziomie jakości B+ są na ogół bardziej rygorystyczne niż na poziomie jakości $\mathrm{B}$, czy poziomie akceptacji 1. Przykładowo, wartości graniczne pęcherzy gazowych (2011) i równomiernie rozłożonych (2012) na poziomie jakości $B$ i na poziomie akceptacji 1 są takie same i wynoszą $3 \mathrm{~mm}$. Na poziomie jakości $B+$ wartość graniczna tych niezgodności jest mniejsza i wynosi $2 \mathrm{~mm}$. Natomiast w złączach spawanych płyt pomostowych (poziom jakości $\mathrm{B}+^{*}$ ) te same niezgodności akceptowalne są wyłącznie w postaci pęcherzy pojedynczych, przy czym należy rozumieć, że ich maksymalny wymiar (średnica) określony jest wymaganiami jak dla poziomu jakości B (rys. 3). Zatem pod względem wartości granicznych analizowanych pęcherzy wymagania 
Tablica III. Porównanie kryteriów akceptacji niezgodności spawalniczych dla poziomów jakości B i B+ oraz poziomu akceptacji 1 wg różnych norm, dla złączy doczołowych ze stali kontrolowanych metodą radiograficzną

Table III. Comparison of acceptance criteria of welding imperfections for quality levels B and B+ as well as acceptation level 1 according to various standards for butt joints in steel examined with radiographic method

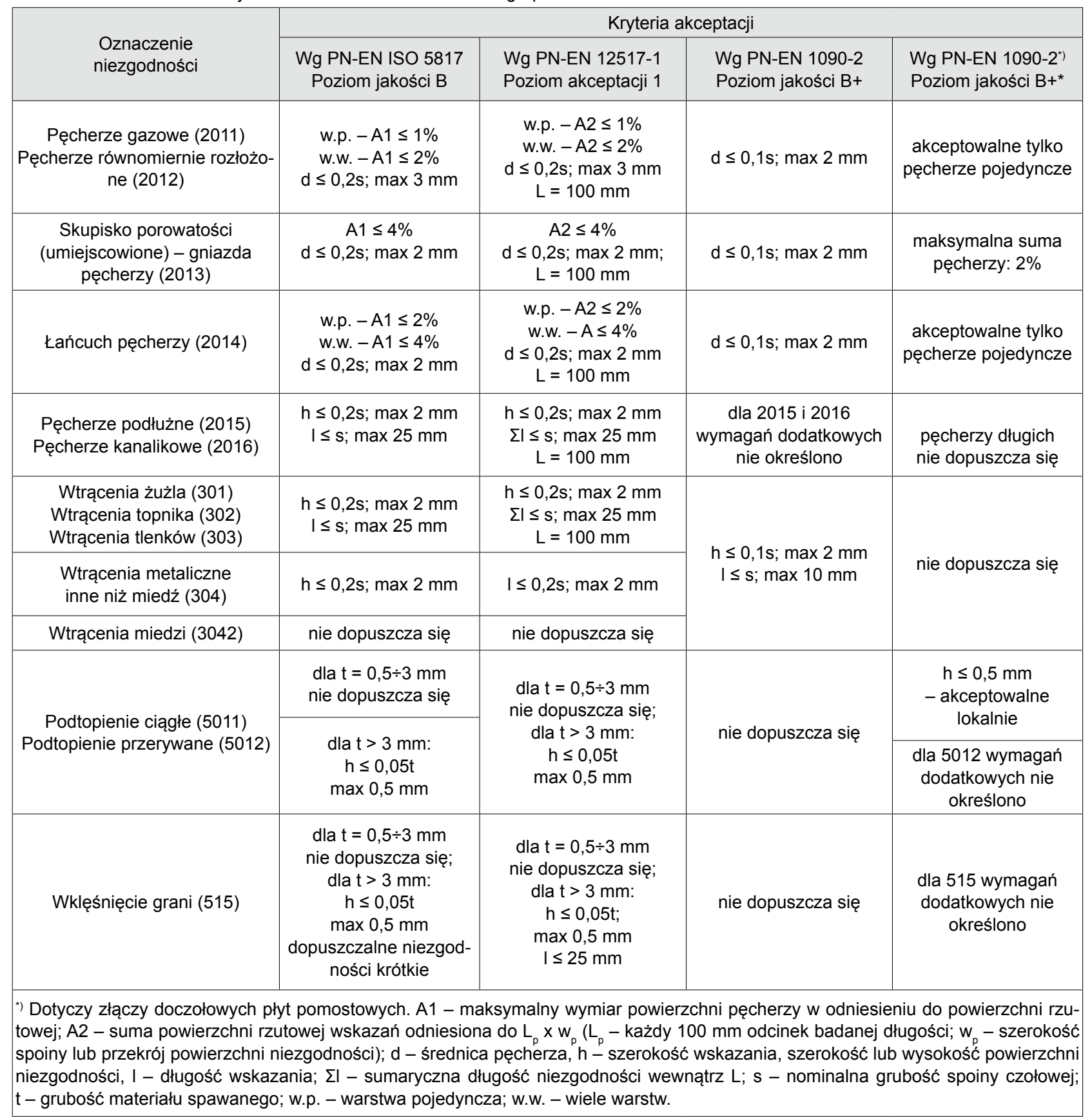

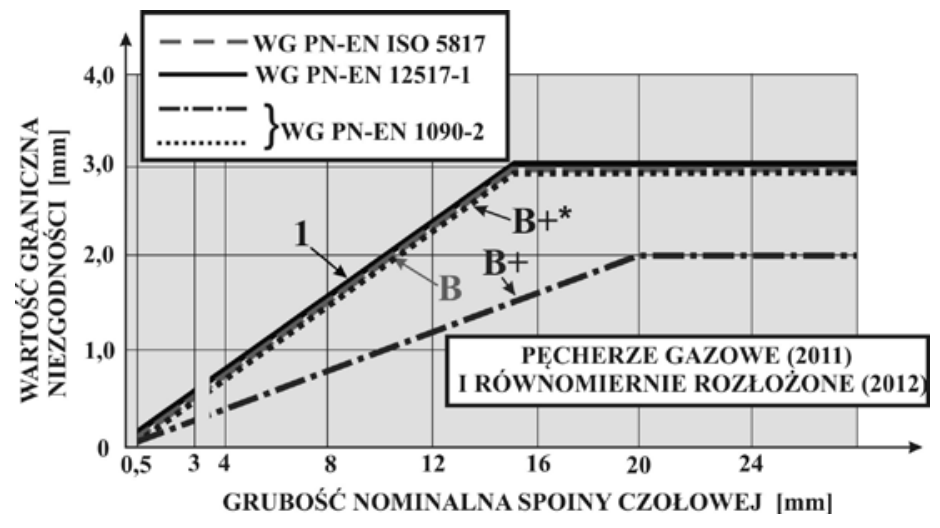

Rys. 3. Wartości graniczne pęcherzy gazowych i pęcherzy równomiernie rozłożonych dla poziomów jakości $\mathrm{B}, \mathrm{B}+, \mathrm{B}+{ }^{*}$ oraz poziomu akceptacji 1

Fig. 3. Limits for gas pores and uniformly distributed porosity for quality levels $\mathrm{B}, \mathrm{B}+, \mathrm{B}+^{*}$ and acceptation level 1 
normy PN-EN 1090-2 należy uznać za ostrzejsze niż norm pozostałych.

Na poziomie jakości B i poziomie akceptacji 1, oprócz wartości granicznych, ustalono również dopuszczalną powierzchnię pęcherzy odniesioną do rzutowanej powierzchni ocenianego odcinka spoiny. Dopuszczalne wartości tego stosunku są w obu przypadkach takie same i wynoszą: $1 \%$ - dla spoiny jednowarstwowej i $2 \%$ - dla spoiny wielowarstwowej. $\mathrm{Na}$ poziomie jakości $B+$ takiego ograniczenia nie podano. Wynikałoby stąd, że pod względem ilości występujących w spoinie pęcherzy wymagania PN-EN ISO 5817 i PN-EN 12517-1 są wyższe niż PN-EN 1090-2. Przyjmując natomiast, że na poziomie jakości $B+$ sformułowano wyłącznie zaostrzenie wymagań (pozostałe wymagania pozostają jak dla poziomu jakości B), to w odniesieniu do pęcherzy gazowych i równomiernie rozproszonych poziom jakości $B+$ charakteryzuje się wyższymi wymaganiami niż poziom jakości B i poziom akceptacji 1. Jak widać, w przedstawionym zakresie wymagania PN-EN 1090-2 nie są jednoznaczne i powinny zostać sprecyzowane.

Do podobnego wniosku prowadzi analiza wymagań dotyczących obecności pęcherzy równomiernie rozłożonych i łańcuchów pęcherzy (2014) w złączach płyt pomostowych, czyli na poziomie jakości $\mathrm{B}+{ }^{*}$ (rys. 4).

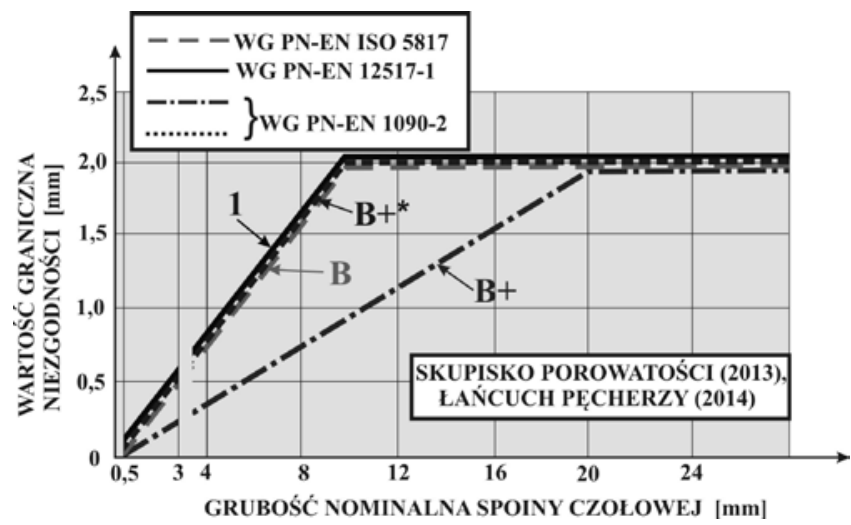

Rys. 4. Wartości graniczne skupisk porowatości (gniazd pęcherzy) i łańcuchów pęcherzy dla poziomów jakości $\mathrm{B}, \mathrm{B}+, \mathrm{B}+{ }^{*}$ oraz poziomu akceptacji 1

Fig 4. Limits for clustered (localised) porosity and linear porosity for quality levels $\mathrm{B}, \mathrm{B}+, \mathrm{B}+^{*}$ and acceptation level 1

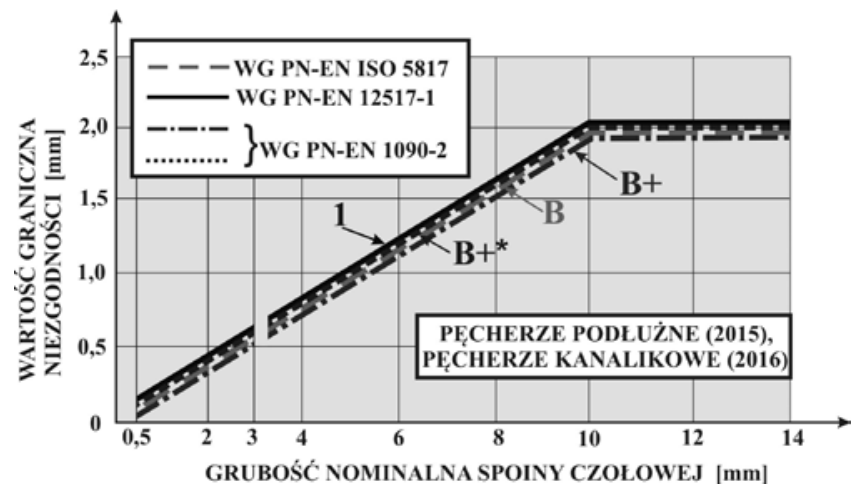

Rys. 5. Wartości graniczne pęcherzy podłużnych i kanalikowych dla poziomów jakości $\mathrm{B}, \mathrm{B}+, \mathrm{B}+{ }^{*}$ oraz poziomu akceptacji 1

Fig. 5. Limits for elongated cavities and worm holes for quality levels $\mathrm{B}, \mathrm{B}+, \mathrm{B}^{*}$ and acceptation level 1
Akceptowalne są tylko pęcherze pojedyncze. Tymczasem z definicji tych niezgodności (podanej w normie PN-EN ISO 6520-1) wynika, że muszą one występować w postaci większej (chociaż bliżej nieokreślonej) liczby indywidualnych pęcherzy gazowych. Przykładowo, jeden lub dwa pęcherze pojedyncze nie mogą tworzyć łańcucha.

W przypadku gniazd pęcherzy (2013) maksymalny wymiar sumy powierzchni rzutowania niezgodności, odniesiony do powierzchni ocenianej, zmniejszono na poziomie jakości $B+o$ połowę. Zatem wymagania normy PN-EN 1090-2 wydają się ostrzejsze niż norm pozostałych.

Kryteria akceptacji pęcherzy podłużnych (2015) i kanalikowych (2016) na poziomach jakości B, B+, $\mathrm{B}+{ }^{*}$ oraz poziomie akceptacji wskazań 1 są takie same (rys. 5).

Dla nominalnej grubości spoiny czołowej s $\geq 10 \mathrm{~mm}$ wartość graniczna niezgodności wynosi $2 \mathrm{~mm}$. W złączach dopuszcza się ich obecność tylko w postaci niezgodności krótkich.

Z dotychczasowej analizy kryteriów akceptacji odpowiedzialnych złączy spawanych ze stali (kontrolowanych radiograficznie) wynika, że sprecyzowanie definicji takich niezgodności, jak: pęcherze równomiernie rozłożone (2012), gniazdo pęcherzy (2013) czy łańcuch pęcherzy (2014) staje się sprawą istotną. Najprostszym rozwiązaniem byłoby przyjęcie definicji podanych w normie PN-74/M-69771, wg której zarówno w gnieździe, jak i łańcuchu pęcherzy muszą występować co najmniej 4 pęcherze w odstępach nie większych niż potrójna średnica pęcherza największego.

Na poziomie jakości $B+{ }^{*}$ wtrącenia stałe (300) oceniane są bardzo rygorystycznie. We wszystkich przypadkach wtrąceń $(301 \div 304,3042)$ ich obecność nie jest akceptowalna (rys. 6 i 7). Na poziomie jakości B i poziomie akceptacji 1 tak ostre wymagania dotyczą tylko wtrąceń miedzi. W przypadku poziomu jakości $\mathrm{B}+$ sytuacja jest niejasna. Z zapisu normatywnego (tabl. III, poz. 5) nie wynika niedopuszczalność występowania wtrąceń miedzi na tym poziomie.

$\mathrm{Na}$ poziomie jakości B i poziomie akceptacji 1 dopuszcza się obecność wtrąceń żużla, topnika

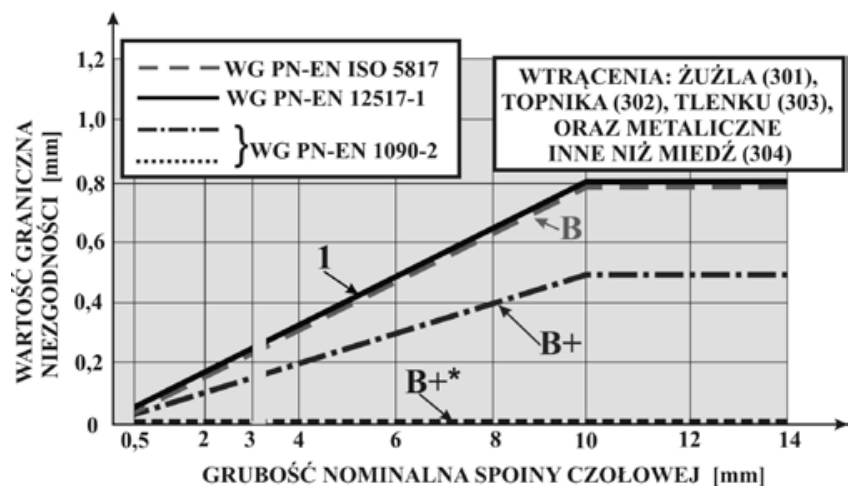

Rys. 6. Wartości graniczne wtrąceń stałych (z wyjątkiem wtrącenia miedzi) dla poziomów jakości $\mathrm{B}, \mathrm{B}+, \mathrm{B}+{ }^{*}$ oraz poziomu akceptacji 1

Fig. 6. Limits for solid inclusion (other than copper) for quality levels $\mathrm{B}, \mathrm{B}+, \mathrm{B}+^{*}$ and acceptation level 1 


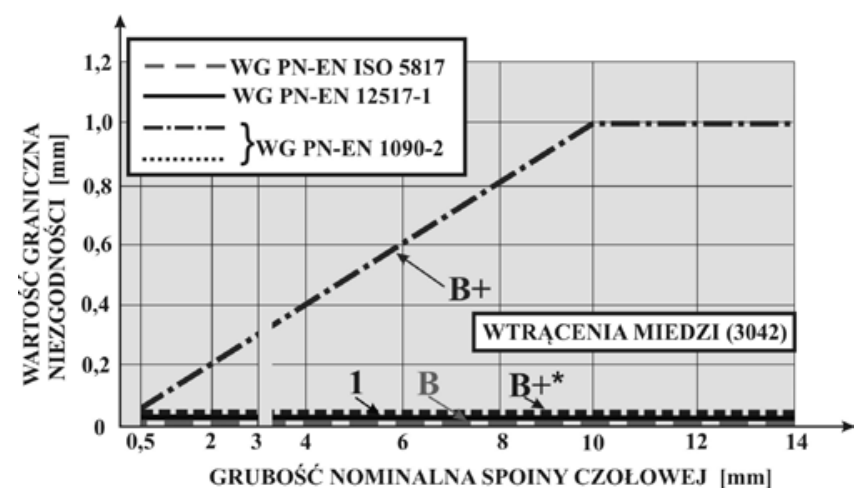

Rys. 7. Wartości graniczne wtrąceń miedzi dla poziomów jakości $B$, $\mathrm{B}+, \mathrm{B}^{*}$ oraz poziomu akceptacji 1

Fig. 7. Limits for copper inclusions for quality levels $B, B+, B+^{\star}$ and acceptation level 1

i tlenków wyłącznie krótkich, czyli nie dłuższych niż $25 \mathrm{~mm}$. Jeszcze mniejsze wtrącenia (zarówno pod względem szerokości, jak i długości) dopuszczono na poziomie jakości $B+$. Jak widać, w przypadku obecności wtrąceń najwyższe wymagania muszą spełniać złącza spawane w płytach pomostowych.

Wiadomo, że wiele konstrukcji stalowych lub ich elementów scala się w warunkach terenowych (na budowie) ręcznie elektrodami otulonymi. Ujawnienie w wykonanych złączach spawanych drobnych wtrąceń żużla jest zatem bardzo prawdopodobne. $Z$ tego powodu wymaganie obowiązujące dla poziomu jakości $\mathrm{B}+{ }^{*}$ czy $\mathrm{B}+$ wydaje się zbyt ostre oraz nieuzasadnione zarówno pod względem technicznym, jak i ekonomicznym.

Z analizy tablicy III wynika również, że zalecenia przedstawione $w$ porównywanych normach bardzo rygorystycznie odnoszą się do obecności w złączach spawanych niezgodności spawalniczych w postaci ciągłych lub przerywanych podtopień od strony lica (5011, 5012) (rys. 8).

Dla grubości materiału spawanego $0,5 \div 3,0 \mathrm{~mm}$ ich obecność w złączach jest niedopuszczalna. Natomiast dla grubości większej niż $3 \mathrm{~mm}$ dopuszcza się obecność niewielkich podtopień od strony lica tylko na poziomach jakości B i B+* (akceptowane lokalnie) oraz poziomie akceptacji wskazań 1 .

W obecności podtopień od strony lica złącze spawane pracuje w warunkach złożonego stanu naprężeń (mimośrodowe rozciąganie - rys. 9).

Zatem przedstawiony sposób oceny wydaje się słuszny. Jednak opublikowano badania, których wyniki prowadzą do wniosku, że przywiązywanie tak dużej jak obecnie wagi do występujących w złączu podtopień nie jest dostatecznie uzasadnione [2].

Bardzo negatywna ocena wklęśnięć grani na poziomie jakości $B+$ również nie znajduje uzasadnienia (rys.10). Wynika to $z$ faktu, że ubytek przekroju nośnego złącza z wklęśnięciami jest na ogół rekompensowany wysokością nadlewu wykonanej spoiny oraz wyższymi, w porównaniu do materiału podstawowego, właściwościami wytrzymałościowymi (rys. 11).

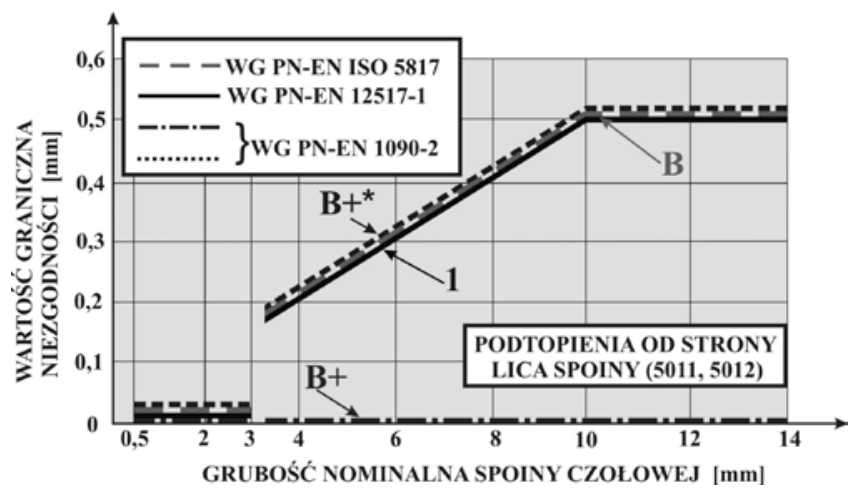

Rys. 8. Wartości graniczne podtopień od strony lica spoiny dla poziomów jakości $\mathrm{B}, \mathrm{B}+, \mathrm{B}+^{*}$ oraz poziomu akceptacji 1

Fig. 8. Limits for undercuts for quality levels $B, B+, B+^{*}$ and acceptation level 1

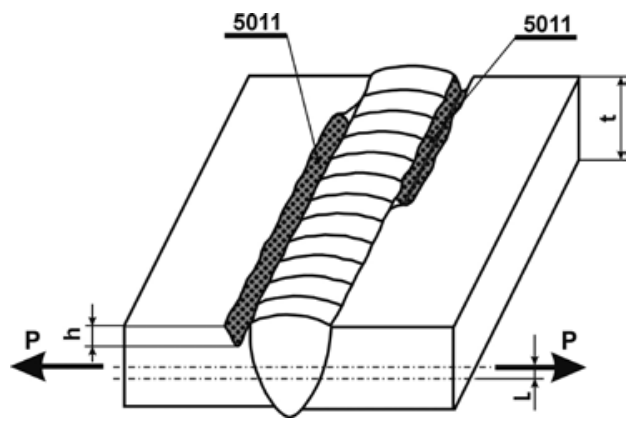

Rys. 9. Oddziaływanie podtopień od strony lica w spawanym złączu doczołowym

Fig. 9. Illustration of the undercut action in butt welded joint

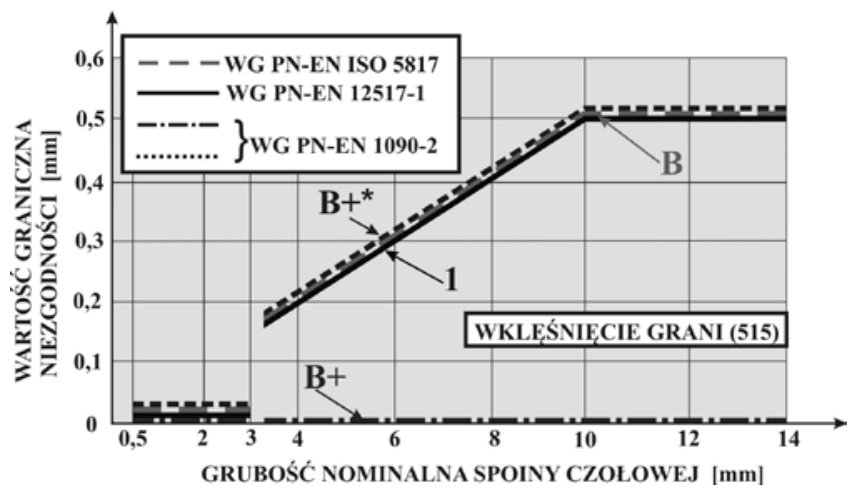

Rys. 10. Wartości graniczne wklęśnięć grani dla poziomów jakości $B$, $\mathrm{B}+, \mathrm{B}^{*}$ oraz poziomu akceptacji 1

Fig 10. Limits for the root concavity for quality levels $B, B+, B+{ }^{*}$ and acceptation level 1

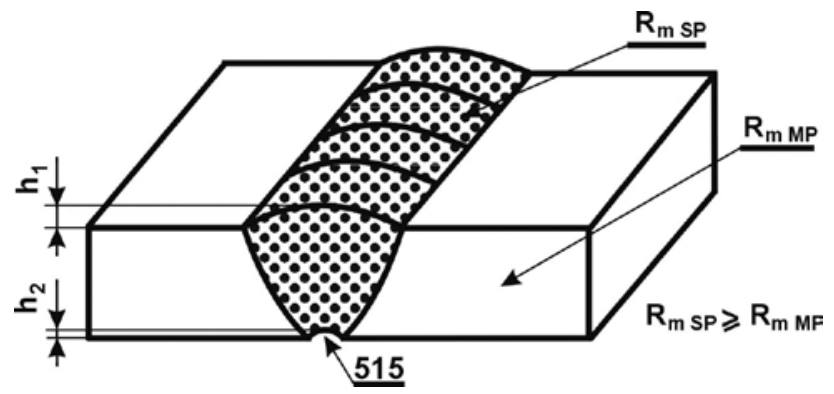

Rys. 11. Poglądowe przedstawienie zasadności łagodniejszej oceny wklęśnięć grani

Fig. 11. Illustration of the rationality of the more lenient assessment of the root concavity 


\section{Podsumowanie}

Dla kryteriów akceptacji charakteryzujących się najwyższymi wymaganiami (poziom jakości $\mathrm{B}, \mathrm{B}+$, $\mathrm{B}^{*}{ }^{*}$ i poziom akceptacji wskazań 1) porównanie norm PN-EN ISO 5817, PN-EN 12517-1 i PN-EN 1090-2 wykazało znaczne podobieństwo zasad oceny jakości złączy spawanych na podstawie badań radiograficznych. W odniesieniu do złączy doczołowych o grubości $0,5 \div 3 \mathrm{~mm}$ oraz niezgodności spawalniczych w postaci wklęśnięcia grani (515) i podtopień od strony lica $(5011,5012)$ ocena jest taka sama. W przypadku złączy o grubości większej niż $3 \mathrm{~mm}$ analiza wartości granicznych niezgodności prowadzi do wniosku, że wymagania normy PN-EN 1090-2 są bardziej rygorystyczne niż norm pozostałych.

Do podobnego wniosku prowadzi również analiza wartości granicznych wtrąceń (300), których obecność na poziomie jakości $B+^{*}$ jest niedopuszczalna w żadnym zakresie. Natomiast wymagań obowiązujących dla poziomu jakości B+ nie można uznać za jednoznaczne.

Podobnie niejednoznaczne są kryteria akceptacji ustalone dla różnego rodzaju pęcherzy (2011 do 2016). Wymagania PN-EN 1090-2 na poziomach jakości $\mathrm{B}+\mathrm{i} \mathrm{B}+^{*}$ dotyczące wartości granicznych tych niezgodności są bardziej rygorystyczne niż wymagania norm pozostałych. Jednak w przypadku pęcherzy równomiernie rozłożonych (2012) i łańcucha pęcherzy (2014) wymaganie przedstawione na poziomie jakości $B+^{*}$ jest dyskusyjne. Trudno bowiem dla tych niezgodności akceptować włącznie pęcherze pojedyncze. Dla pęcherzy podłużnych (2015) i kanalikowych (2016) wymagania analizowanych norm są takie same. Akceptuje się tylko niezgodności krótkie.
Norma PN-EN 1090-2 charakteryzuje się, jak każde nowe opracowanie, pewnymi niedoskonałościami. Może to powodować nieporozumienia $w$ interpretacji przedstawionych $w$ niej wymagań. $Z$ tego powodu warto, naszym zdaniem, poddać zawartość normy analizie przed jej szerokim upowszechnieniem w praktyce przemysłowej. Przedstawione porównanie i jego wyniki należy traktować jako głos w tego rodzaju dyskusji.

$\mathrm{Na}$ podstawie przeprowadzonego porównania można sformułować następujące wnioski:

- w zakresie oceny jakości złączy spawanych na podstawie badań radiograficznych wymagania PN-EN ISO 5817 i PN-EN 12517-1, dla poziomu jakości B i poziomu akceptacji wskazań 1 , są takie same lub bardzo zbliżone;

- z punktu widzenia wartości granicznych niezgodności spawalniczych wymagania PN-EN 1090-2 są wiekszą niż PN-EN ISO 5817 i PN-EN 12517-1;

- wświetle wymagań dotyczących obecności pęcherzy równomiernie rozłożonych (2012) i łańcuchów pęcherzy (2014) w złączach płyt pomostowych na poziomie jakości $B+$ zachodzi konieczność sprecyzowania definicji tych niezgodności;

- przed wdrożeniem PN-EN 1090-2 do szerokiego stosowania w praktyce przemysłowej zasadność ustanowienia specjalnych wymagań, w postaci poziomu jakości $\mathrm{B}+$, powinna być poddana merytorycznej, powszechnej dyskusji.

\section{Literatura}

[1] Augustyn J., Śledziewski E.: Technologiczność stalowych konstrukcji spawanych. Arkady. Warszawa, 1974.

[2] Robakowski T.: Wpływ wad w złączach spawanych na własności eksploatacyjne konstrukcji spawanych. Wydawnictwo Instytutu Spawalnictwa. Gliwice, 2005.

[3] Staniszewski K., Sikora S., Czuchryj J.: Ocena jakości złączy spawanych $w$ konstrukcjach budowlanych na podstawie badań radiograficznych i poziomu jakości B+. Biuletyn Instytutu Spawalnictwa $\mathrm{nr}$ 5/2011.

[4] Wichtowski B., Wichtowski M.: Normatywne wymagania wykonawcze i spawalnicze w konstrukcjach budowlanych oraz badania jakości spoin. Przegląd Spawalnictwa nr 3/2012.

[5] Czuchryj J., Sikora S., Staniszewski K.: Ocena jakości złączy spawanych płyt pomostowych wg wymagań normy PN-EN 1090-2 na podstawie poziomu jakości B+. Biuletyn Instytutu Spawalnictwa $\mathrm{nr}$ 2/2012.

[6] Brózda J., Czuchryj J.: Radiografia złączy spawanych. Wydawnictwo Instytutu Spawalnictwa. Gliwice, 2005.

[7] Czuchryj J., Papkala H., Winiowski A.: Niezgodności w złączach spajanych. Wydawnictwo Instytutu Spawalnictwa. Gliwice 2005.

\section{Wykaz norm}

- PN-EN ISO 5817:2009 Spawanie - Złącza spawane ze stali, niklu, tytanu i ich stopów (z wyjątkiem spawanych wiązką) Poziomy jakości według niezgodności spawalniczych.

- PN-EN ISO 5817:2009 /A1 Spawanie - Złącza spawane ze stali, niklu, tytanu i ich stopów (z wyjątkiem spawanych wiązką) - Poziomy jakości według niezgodności spawalniczych.

- PN-EN 12517-1:2008 Badania nieniszczące spoin - Część 1: ocena złączy spawanych ze stali, niklu, tytanu i ich stopów na podstawie radiografii - Poziomy akceptacji.

- PN-EN 17635 Badania nieniszczące spoin - Zasady ogólne dotyczące metali.

- PN-EN 1090-2 Wykonanie konstrukcji stalowych i aluminiowych - Część 2: Wymagania techniczne dotyczące konstrukcji stalowych.

- PN-EN 1993:2006 Eurokod 3 - Projektowanie konstrukcji stalowych - Część 2: Mosty stalowe.

- PN-74/M - 69771 Spawalnictwo - Wady złączy doczołowych wykrywane badaniami radiograficznymi - Nazwy i odniesienia. 